\title{
Mediating effect of behavioural intention on podcast acceptance
}

\author{
Adu Emmanuel Ifedayo ${ }^{1}$ (D) Azidah Abu Ziden ${ }^{1} \cdot$ Aziah Binti Ismail $^{1}$
}

Received: 2 September 2020 / Accepted: 9 November 2020/ Published online: 13 November 2020

(C) Springer Science+Business Media, LLC, part of Springer Nature 2020

\begin{abstract}
This research contributes to knowledge in mediating effect of lecturers' behavioural intention towards the acceptance of podcasts technology in universities. A crosssectional quantitative research design was involved in this study. Also, a total of eight hundred and twenty-nine (829) lecturers participated in this research from three different south-west Nigeria Federal universities. The research instrument was titled lecturer's acceptance questionnaire (LAQ) with a calculated Cronbach's alpha of .919, which confirmed the instrument validity. The gathered data was analysed by using both descriptive and inferential statistics. The formulated hypothesis was tested at .05 level of significance. The result from descriptive analysis of data suggested that behavioural intention was at a low level among lecturers and the results of hypothesis testing revealed the effect of behavioural intention as partial mediator of podcast acceptance. Based on these findings relevant conclusions and recommendations were suggested in this research.
\end{abstract}

Keywords Mediating effect - Behavioural intention · Podcast acceptance $\cdot$ Educational technology use

Adu Emmanuel Ifedayo

aduifedayoemmanuel@student.usm.my

Azidah Abu Ziden

azidahziden@gmail.com

Aziah Binti Ismail

aziah@usm.my

1 School of Educational Studies, Universiti Sains Malaysia, P.M.B 11800, Gelugor,

Penang, Malaysia 


\section{Introduction}

Podcasts are online resources meant for teaching and learning purposes. Podcasts are useful for student centered form of instruction by providing learners with options to learn at their own pace and convenience. Podcasts are ubiquitous online resources which are accessible through iPhones, android phones and computer systems. Podcasts are easy to use technology for instruction as it provides flexible options to lecturers for exploring varieties of approaches towards lectures. Podcasts are downloadable online resources through digital mobile technologies (Clarke et al. 2020).

However, there are limited research evidences that adequately addressed the mediating effect of behavioural intention on podcast acceptance in Nigeria universities. Previous research dealt with issues regarding podcasts without considering the mediating effect of behavioural intention towards podcast acceptance in a developing country context like Nigeria. For instance, Torres (2011) previous research investigated podcasting issues without addressing the effect of behavioural intention on podcasts utilisation.

This research is significant to universal audience by providing empirical backing in the light of scarcity of logical evidences to adequately explain the mediating effect of lecturers' behavioural intention towards podcast acceptance in universities. This research has not only explained the mediating effect of behavioural intention towards podcasts as it also explored the levels of lecturers' behavioural intention towards podcasts in Nigeria universities. This research results are significant towards shedding light on dilapidated infrastructural systems, which are meant to support podcast acceptance in Nigeria universities. Podcasts are indispensable instructional technologies in this twenty-first century due to their flexibility (Bralić and Divjak 2018).

\subsection{Problem statement}

The Nigerian higher education culture still favours face-to-face interaction as opposed to online communication. For instance, Obilade (2013) research noted that some of the lecturers in Nigerian universities prefer to use face-to-face teaching approach. The author added that the reason emanates from inadequate facilities to support online communication (Obilade 2013). Okundaye et al. (2019) noted that cultural belief in a country affects the acceptance of technologies. Also, Mehta et al. (2019) study revealed that cultural influence is paramount towards technology acceptance. As these set of lecturers continue to hold on to this culture the situation creates a vacuum in the acceptance of podcasts contents for university education (Eze 2013).

In addition, Panday (2009) noted that higher education lecturers are normally reluctant in putting additional effort towards the adoption of digital technologies for educational purposes. The lecturers' inadequate acceptance towards podcast in Nigeria higher education impedes access to standard and updated educational resources (Echezona and Ugwuanyi 2010). Also, this inadequate acceptance of podcast creates insufficient intimacy with the latest development in subject area of practice (Echezona and Ugwuanyi 2010). Hence, researchers have prescribed for further enquiry towards podcasting in advanced educational systems (Wong et al. 2013).

A lecturers' childhood training sometimes determines social views. It is socially evident that the Nigerian native social practice does not support the use of digital 
technologies. For instance, the people holding on to customary social believes prefer physical interaction than online (Abioye 2011). Ma and Lee (2019) acclaimed social belief as influence towards acceptance of technologies. Kincsei (2007) study likewise revealed that social view controls the adoption of technologies in an environment. Additional research showed that social view determines the way a technology influences a community (Huang and $\mathrm{Li}$ 2017). This opens the opportunity for this enquiry to further investigate social factor influence towards podcasting in Nigeria higher education situation. The reason being that the use of podcast in this study is within a university context that entails the lecturers' and students' interaction with one another. Although, the Federal and State Government of Nigeria had made ample efforts in securing some podcasting amenities and structures in most institutions in accordance with the National Policy on Education (NPE) (Ayodele and Akindutire 2009). The shortfalls regarding inadequate acceptance of technologies for education leads to continuous reduction in university rankings (Okebukola 2011). Also, the social belief problem causes poor lecturer research quality in this West African country (Okebukola 2011).

Thus, additional enquiry that stimulates the lecturers' acceptance towards podcasting was acclaimed as being necessary in Nigerian higher education setting (Garuba 2013). The militating factors against technology decreases lecturers' level of interest towards podcast usage (Garuba 2013). The militating factors against podcast technology reduces lecturers' morale to interact with counterparts from other parts of the world (Adu 2017). Similarly, these militating factors makes situations difficult for the lecturers to impart into students' the necessary skills required to secure employment in a competitive job market that is technology driven (Brodahl et al. 2011). Also, in this COVID-19 pandemic era that is characterised with restricted movement of people the militating factors impede the introduction of technologies as palliative to ensure continuity in university educational activities (Ifijeh and Yusuf 2020). This shows the necessity for rapid awareness creation on the acceptance of technologies through quality research effort (Ntui and Usang 2014).

The lecturer's political belief in Nigeria is a problem factor that was addressed in this research due to desire to select leaders with the most convincing plan towards the development of podcast resources. This is the believe in good leadership since a leader helps with the financing of podcast facilities. Positive political belief helps in reducing infrastructural deficit for technology adoption in educational system (Barakabitze et al. 2019). However, the lecturers' political beliefs had met with many challenges through the years. The lecturers are normally inadequately informed about the right leader to select into political positions. Available research showed that political belief is embedded in Nigeria educational activities since it is assumed to be capable of solving some of the educational problems in the country (Osuji 2011). In addition, Moja (2000) study affirmed that political factors are linked to learning practices in Nigeria since some of the Nigerian educational establishments are financed by the Government. Similarly, Ikegbusi et al. (2016) research asserted that political factors are associated with educational endeavours in Nigeria since the selected Government determines the selection of managers for educational institutions in the country.

Although, numerous researches to mention for example by Ang'ondi (2013, p. 21) with Barnes and Kennewell (2017, p. 2485) addressed problems related to the lecturers' 'attitudes and perceptions' towards media resources. Podcast is considered as media 
resources (Berry 2015). Media resources are materials for disseminating teaching and learning contents (Omodara and Adu 2014). Notwithstanding, there are limited enquiries that adequately fills the gap on difficulties associated with the lecturers' podcasting for higher learning in South-West Nigeria Federal universities. Thus, this research proposed to fill the mounting gap that exist in the lecturers' acceptance of podcast. This mounting gap is a disconnection between the developed and developing country context podcast acceptance level for teaching and learning activities. However, the context of this study was in a developing country with focus on South-West Nigeria Federal universities lecturers' and factors creating the gap in podcast acceptance. Garuba (2013) claims these gaps creates imbalances in institutional performance. The author further suggested that higher education must start researching, creating and utilising online media frequently to reduce the disparities in this area (Garuba 2013).

The lecturer's performance expectancy factor addresses the issues surrounding the students' performances. Venkatesh et al. (2003) noted this factor as capable of influencing technology adoption. Podcast is also a technology in South-West Nigeria Federal universities. Performance expectancy is related to students' achievement, which is derived by using technologies (Mensah 2019). However, some of the lecturers believe this digital media do not have the capability of transforming the learners' performances. Nevertheless, how to boost the students' achievement had been serious concerns to some Nigeria higher education establishment (Borisade 2013). If the lecturers continue to think that podcasts do not have advantage. Then lecturers risk limiting the students' performances (Venkatesh et al. 2003; Ayodele and Akindutire 2009). This is due to insufficient quality of instruction being delivered on daily basis in workplace (Venkatesh et al. 2003; Ayodele and Akindutire 2009).

Effort expectancy is another problem (Venkatesh et al. 2003). The south-west Nigeria lecturers' effort expectancy makes the lecturers to believe that podcasting activities is stress free. There are some set of lecturers that believe that podcasting activities are difficult to use in the Nigeria Federal higher educational setting. Podcast is a time saving teaching media (Hersch 2017). Hence, effort expectancy makes users of technology feel at ease (Nistor et al. 2014). Effort expectancy connote the ease with use of instructional technologies (Yakubu and Dasuki 2019). The effort expectancy factor must convince the lecturers that podcasts creates a very efficient educational system. Otherwise, refusal to accept podcasting resources for teaching and learning purposes makes instructional procedures very cumbersome in this modern time in Nigeria (Omede 2015).

The lecturers social influence is another factor regarding the acceptance of technology (Venkatesh et al. 2003). The social influence likewise addresses the lecturers' conviction as to whether podcast acceptance in South-West Nigeria Federal universities is not impacting the school environment. Social influence is the influence by people in an environment (Idoga et al. 2019). Podcasts must transform the university system (Hew 2009). However, some lecturers assume that podcasting activities are of no relevance to university setting. Some lecturers believe that theoretical knowledge of podcasting is enough to impact the Nigerian university campus (Ukwueze and Okpulo 2014). The lecturers' refusal to accept podcast limits the learners' interest towards Nigerian based higher education (Okebukola 2011).

The lecturers and facilitating conditions are another problem with technology acceptance (Venkatesh et al. 2003). Facilitating conditions are linked with facilities 
availability on campus (Venkatesh et al. 2003). Inadequate facilitating conditions militate against the acceptance of technologies (Foluke 2019). The facilities required for podcasting tasks are insufficient to promote the lecturers' acceptance of podcast media for educational endeavours in South-West Nigeria Federal universities. Sometimes, the conditions of these facilities vary from one higher education to the other. For instance, some facilities are available in the lecture hall and functioning well to support the expected podcasting purpose (Okebukola 2011). The facility availability promotes podcasts acceptance in South-West Nigeria Federal universities. Other facilities are available and not functioning in the lecture halls, which limits podcast acceptance. In this COVID-19 pandemic era there were limited facilities required to promote the use of technologies as palliative to ensure continued teaching and learning activities in Nigeria universities (Jacob et al 2020). There were also some situations where there existed limited podcasting installations in lecture halls (Okebukola 2011). The absence of podcast installations impacts negatively on the ability of the lecturers to teach effectively in a very largely populated lecture room (Schonwetter 1993). Inadequate podcast installations also create difficulties in class control (Schonwetter 1993). Tandon (2020) study revealed that inadequate facilities affect technology adoption for education.

The behavioural intention factor addressed the problem related to lecturers' inner motive towards the acceptance of podcast. Some lecturers in south-west Nigeria Federal universities have negative behavioural intention towards podcast. Behavioural intention factor has influence on technologies acceptance (Shiferaw and Mehari 2019). This behavioural intention problem is part of UTAUT framework that is considered as an influence towards technology adoption by Venkatesh et al. (2003). Ayoade (2015) noted that although there is extensive availability of technologies in Nigeria. Notwithstanding, the adoption of these technologies for teaching and learning purposes is rare (Ayoade 2015). Oladejo et al. (2018) recommended for further studies to know the determinants of behavioural intentions to use technology in Nigeria. These authors added that research on behavioural intention to use technology must enhance the use of technologies (Oladejo et al. 2018). Likewise, Kabir et al. (2017) noted that Nigerians are normally finding the adoption of technologies in place of work difficult. It is imminent to investigate behavioural intention factor within a learning environment (Ibrahim 2018). The author added that few researches have clear understanding of the nature of behavioural intention on technology adoption in Nigeria educational setting. If behavioural intention factor is not investigated this impedes the growth of technology use for education in Nigeria (Ibrahim 2018).

The use behavior factor addresses problems, which are related to lecturers' actions towards podcast acceptance in this research. Some lecturers in south-west Nigeria Federal universities have negative use behavior towards podcast technologies. Use behaviour impacts technology acceptance (Idoga et al. 2019). Just like behavioural intention the use behavior is an original factor derived from UTAUT framework by Venkatesh et al. (2003). Eze et al. (2018) research findings shows that there are difficulties in the use of technologies for instruction in Nigeria. Hence, the authors recommended for additional studies that focus on gathering large amount of data regarding technologies use in Nigeria higher education (Eze et al. 2018). The refusal to use technology for teaching activities usually limits positive transformation within educational system (David et al. 2012). 


\section{Conceptual background}

\subsection{Theoretical framework}

In this study Unified Theory of Acceptance and Use of Technology (UTAUT) model was adopted and adapted. This UTAUT model is technology oriented and permits the studying of any learning media for future use (Rahi et al. 2019). The UTAUT gives better clarification regarding the likely predictors of the acceptance of technology (Vega et al. 2019). The UTAUT specifically aim at addressing issues regarding reluctance towards accepting up-to-date instructional technologies (Al-Saedi et al. 2019). Venkatesh et al. (2003) made several recommendations on issues pertinent to subsequent integration of UTAUT framework for research activities. For instance, Venkatesh et al. (2003) suggested that future enquiries must focus at achieving broader view of UTAUT framework. Also, it was added that future studies must move further on the analysis of major factors in the UTAUT to clearly explain the possible benefits of adopting latest media within any establishment (Venkatesh et al. 2003).

\subsection{Critique of underlying theories}

This study critiqued some theories related to this research framework. Theory of reasoned action (TRA) was one of these theories. The examination of these theories allowed the researcher to have a rationale for choosing unified theory of acceptance and use of technology (UTAUT), since these theories are basic ingredient to UTAUT. Hence, this study refers to these concepts as underlying theories to UTAUT. This critique was necessary to determine the most suitable framework for this study. For instance, the theory of reasoned action (TRA) states that adoption of any media depends on individual's conduct (Alryalat et al. 2020). Also, the TRA theory contains belief factors (Hagger 2019). The theory of reasoned action was proposed by Ajzen and Fishbein (1969).

Another theory critiqued is theory of planned behaviour (TPB). The TPB was critiqued since it contains the intention factor (Hall et al. 2019). For instance, this TPB model has some factors which are like the theory of reasoned action (TRA) (Passafaro et al. 2019). Examples of these factors are 'attitude, subjective norm, behaviour and behavioural intention' (Nisson and Earl 2015, p.16). However, the 'perceived behavioural control' (PBC) is new introduction in the TPB (Tornikoski and Maalaoui 2019). Otherwise, TRA and TPB models are similar without PBC (Norman et al. 2019). The introduction of $\mathrm{PBC}$ was for a unique purpose, which makes the difference between TRA and TPB models (Norman et al. 2019). The TPB is concerned with behaviour (Judge et al. 2019). The TPB model seeks to know the factors that influences behaviour (Judge et al. 2019). Thus, the TPB seeks to contribute more understanding to behaviour concept (Clark et al. 2019). The perceived behavioural control (PBC) factor in theory of planned behaviour (TPB) is the awareness of how convenient or hard a behaviour becomes in a situation (De Vivo and Mills 2019). The PBC factor is the prediction of the complexity of a pending action (Nisson and Earl 2015). The theory of planned behaviour (TPB) was proposed by Ajzen (1991).

The third underlying theory critiqued in this study is social constructivist theory (SCT). For instance, the learners' social environment are active learning ingredients 
under the SCT (Ahmadi 2019). Some of the environmental elements in SCT are traditional practices, which are means for social interaction by the students in a community (Landefeld 2019). Also, peer group social interaction in SCT is another element that determines the students learning processes (Khadimally 2019). The SCT allow learning process to occur with the contribution of everyone present in an environment (Teague 2000). The social constructivist theory was proposed by Vygotsky as noted by Yu (2017).

\subsection{Rationale for choosing UTAUT}

Unified theory of acceptance and use of technology (UTAUT) was chosen as a favourite model above theory of reasoned action (TRA), theory of planned behaviour (TPB) and social constructivist theory (SCT) in this research. The UTAUT addressed more pertinent issues regarding technology acceptance (Garone et al. 2019). There are lecturer concerns regarding students' academic performances and technology adoption in some Nigeria Federal universities (Ahlan et al. 2014). However, TRA, TPB and SCT did not address performance factors (De Vivo and Mills 2019; Khadimally 2019; Kim and Byun 2019). Hence, UTAUT was selected since it had the factor called 'performance expectancy' (Venkatesh et al. 2003, p. 425). The performance expectancy deals with learners' performances (Venkatesh et al. 2003). Also, there are recommendations that addressed issues surrounding the availability of technology facilities in some Nigerian universities (Babatope 2010). The TRA, TPB and SCT did not adequately address issues on technological facilities in universities (Ahmadi 2019; Norman et al. 2019; Xiao 2020). Notwithstanding, UTAUT has the 'facilitating condition' factor on technology (Venkatesh et al. 2003) (Figs. 1, 2, and 3).

The UTAUT variables are explained as follows.

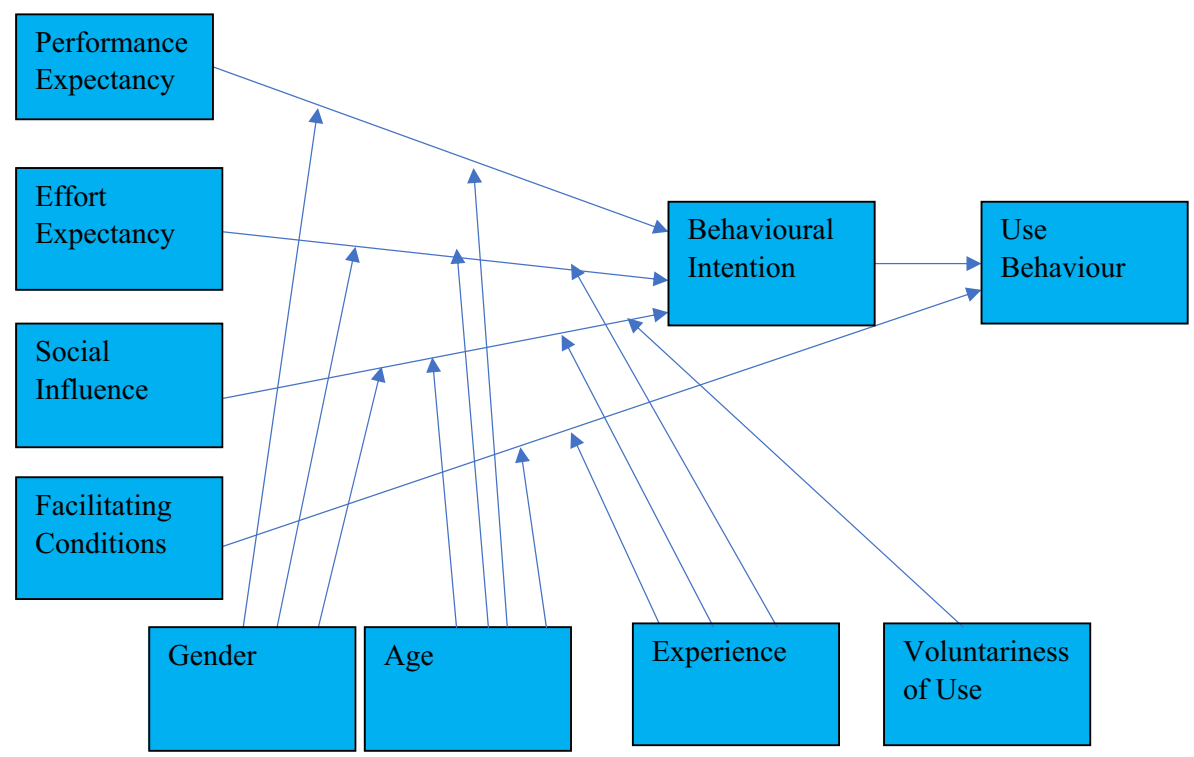

Fig. 1 Theoretical framework of this study. Source Venkatesh et al. (2003). Gender, Age, Experience and Voluntariness of use was not considered in this research 


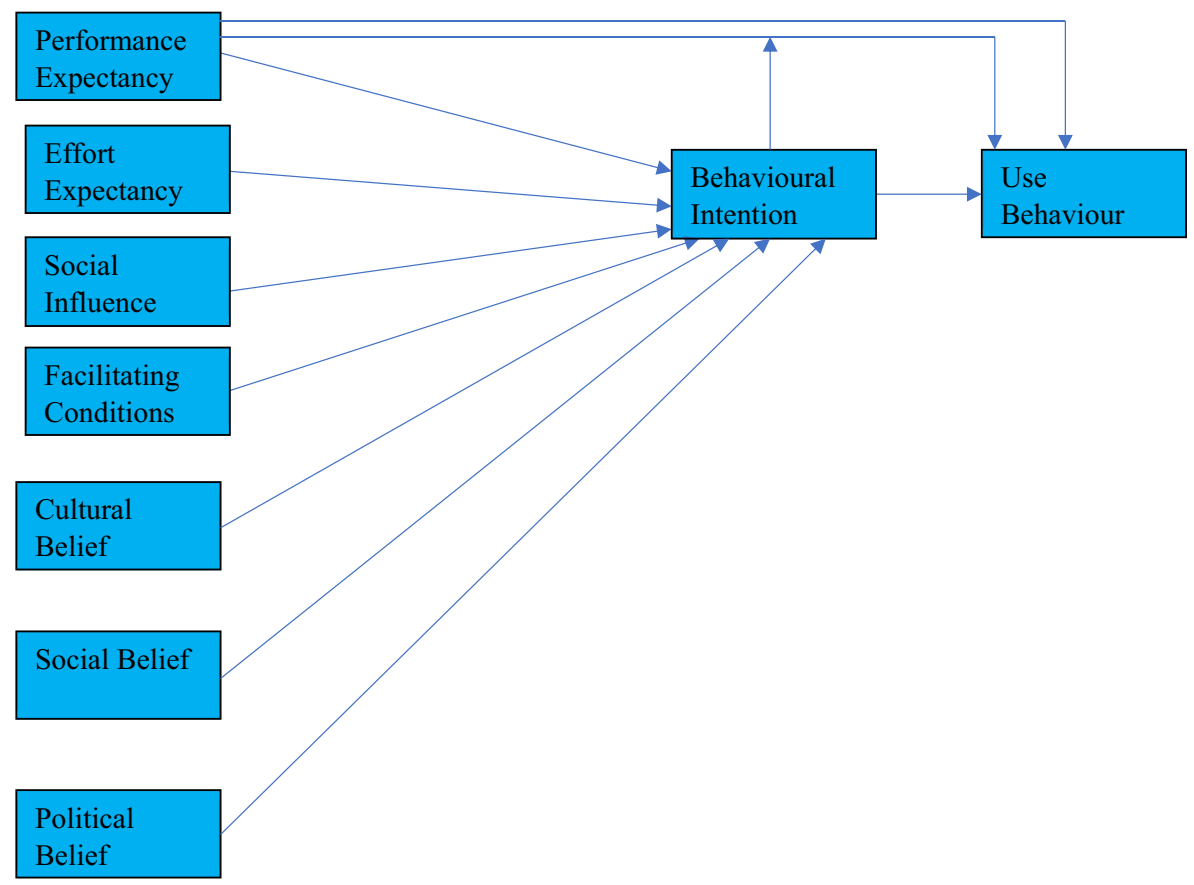

Fig. 2 Conceptual framework. Source: Adapted and Adopted from Venkatesh et al. (2003). Performance expectancy, effort expectancy, social influence, facilitating conditions, cultural, social and political believes are independent variables. Behavioural intention is a mediating variable. Use behaviour is a dependent variable

\subsubsection{Performance expectancy}

This is the extent, which lecturers accept that adopting technology is useful towards the students' educational performances.

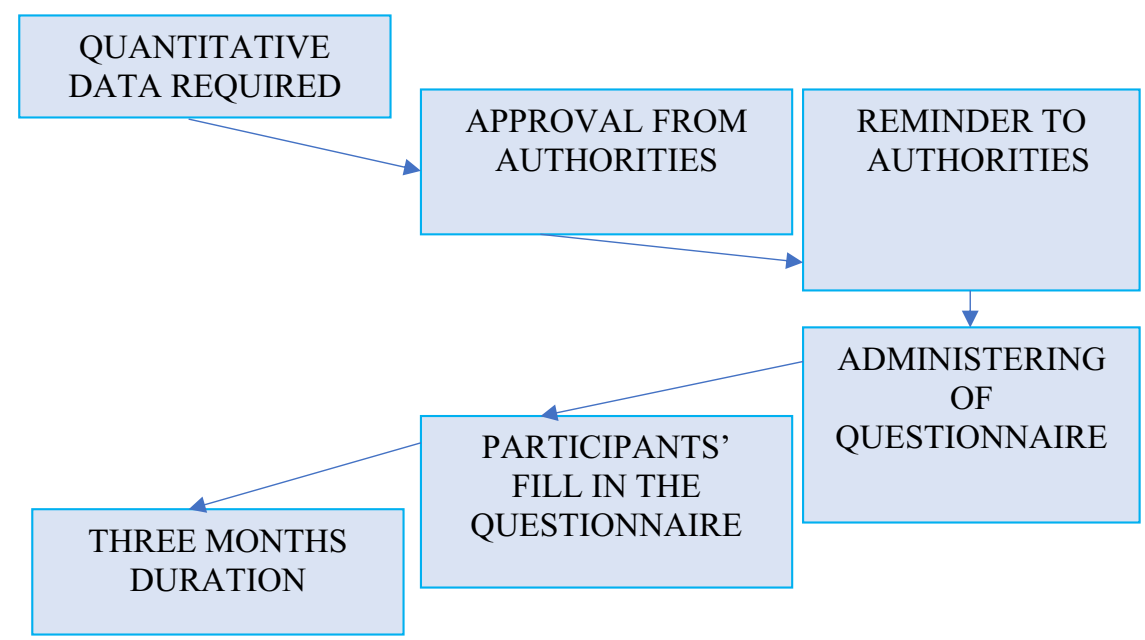

Fig. 3 Flow chart. Source: Anonymous (n.d. p.91) 


\subsubsection{Effort expectancy}

The lecturer's effort expectancy is the extent, which technology activities are easily accessible for instruction.

\subsubsection{Social influence}

The lecturers' social influence is the extent, which lecturers' makes other people to admit the acceptance of technology.

\subsubsection{Facilitating conditions}

The lecturers' facilitating conditions are the levels, which lecturers feel that there are facilities to support technology adoption for instruction.

\subsubsection{Behavioural intention}

The lecturer's behavioural intention is the inner motive to accept technology for instructional purposes.

\subsubsection{Use behaviour}

The use behavior factor in this study is lecturers' actions towards podcast acceptance.

\subsection{Conceptual framework}

The conceptual framework consists of cultural, social and political believes as new factors, which were added to UTAUT. Cultural beliefs are views held by lecturers regarding practice (Sunny et al. 2019). The social beliefs regard the communal activities while political beliefs are connected to leadership matters (Zuidervaart 2019; Regan and Talat Khwaja 2019). A potential technology user having these believes assume the preservation of these cultural, social and political believes must be of utmost concern when using technology for education (Ding et al. 2019; Lemon and Garvis 2019; Kizgin et al. 2019). Culture is a norm (Oyserman 2017). Social belief regards livelihood (Kaplan and Haenlein 2010). Political belief regards leadership matters (Jost et al. 2009).

The research objectives, questions and hypothesis have theoretical support from this study conceptual framework. These objectives, questions and hypothesis are stated as follows.

\subsection{Research objectives}

1. To investigate the level of behavioural intention of using podcast among lecturers in Nigeria Federal universities.

2. To investigate the significant mediator influence of behavioural intention on the relationship between each independent variable and use behaviour of Nigerian lecturers for podcast, where the independent variables are: 

a. performance expectancy,
b. effort expectancy,
c. social influence,
d. facilitating conditions,
e. cultural belief,
f. social belief and
g. political belief.

\subsection{Research questions}

1. What is the level of behavioural intention of using podcast among lecturers in Nigeria Federal universities?

2. Is there any significant mediator influence of behavioural intention on the relationship between each independent variable and use behaviour of Nigerian lecturers for podcasts, where the independent variables are?
a. performance expectancy,
b. effort expectancy,
c. social influence,
d. facilitating conditions,
e. cultural belief,
f. social belief and
g. political belief.

Hypothesis $\mathbf{H O}_{1}$ There is no significant mediator influence of behavioural intention on the relationship between each independent variable and use behaviour of Nigerian lecturers for podcasts, where the independent variables are:
a. performance expectancy,
b. effort expectancy,
c. social influence,
d. facilitating conditions,
e. cultural belief,
f. social belief and
g. political belief.

\subsection{Research methodology}

\subsubsection{Research design}

This research was a cross-sectional quantitative study, which utilized survey method as research design. Survey method refers to the process that allows the researcher to 'quantitatively describe specific aspects of a given population' (Glasow 2005, p. 1). 
Survey method allows the researcher to gather large amount of data from respondents (Glasow 2005).

\subsubsection{Research instrument}

This research utilised an instrument titled lecturer's acceptance questionnaire (LAQ). This study adopted and adapted questionnaire from existing literature evidences. The number of items contained in the research instrument was sixty-four. The questionnaire contained four-point Likert rating scale of agree (A), strongly agree (SA), disagree (D), strongly disagree (SD).

\section{Validation of research instrument}

The validation of this research instrument was conducted at the expert level to establish face and content validity. For instance, the research instrument was presented to experts in area of educational technology, language and test measurement and evaluation for validation.

\subsection{Reliability}

The reliability coefficient of this research instrument was conducted through a pilot study that involved thirty (30) Nigeria university lecturers. The calculated Cronbach alpha was .919, which showed that this research instrument is valid and reliable for data gathering activities.

\subsection{Research participant}

The research participants in this study involved eight hundred and twenty-nine (829) Nigeria Federal universities lecturers.

\subsection{Sampling technique}

This research sampled selected lecturers from three (3) different south-west Nigeria Federal universities by using simple random sampling technique. The randomisation processes entailed the act of assigning numbers to lecturers. Also, the faculties names were written on papers and crumpled up into balls. The crumpled papers were placed in bowls from which the selection was made at random. In addition, the researcher likewise crumpled the lecturers' numbers written on papers and placed them into bowls for random selection. This allowed the selection of each lecturer's based on the chosen number from the bowl.

These three (3) universities were sampled due to the researchers' knowledge of availability of facilities to support podcast acceptance for teaching and learning activities. Hence, these three Federal universities were sampled from three different states in south-west Nigeria. For instance, the first Federal university had a population of 2000 lecturers' (UniRank 2018). The second Federal university had a population of 1343 lecturers' (FME 2011). The third Federal university had a population of 439 lecturers' 
(FME 2011). Thus, these three universities lecturers' target population was calculated by adding the population as estimated, which gave a total of 3782 lecturers.

In calculating the sample size for this study, the lecturers' required from the first Federal university was 322. In the second Federal university 302 participants were required. Also, there were 205 participants required from the third Federal university in Nigeria. The participants were drawn from various faculties like engineering, health science, social science, science, arts and humanities. The total sample size for lecturers' target population of 3782 was estimated to be 829 by using Krejcie and Morgan (1970) table. The response rate was $69.1 \%$.

\subsection{Procedure for data collection}

The data collection had quantitative contents. Also, the researcher requested for approval from necessary authorities like the project supervisor to have the opportunity to initiate the preparation towards going to those universities involved in this study in Nigeria. In addition, there was constant reminder sent to concerned authorities in the universities involved in this research to increase the awareness regarding the intended data gathering procedures. The researcher individually administered the instrument. The participants personally completed the questionnaire. The data gathering procedures were accomplished within three months. The flow chart of the procedure was shown in Fig.3.

\subsection{Ethical issues}

This research observed ethical issues during data gathering activities by ensuring that no lecturer was forced to participate in this study. The researcher also ensured that no lecturer was endangered during data gathering processes. In addition, lecturers were given the right to remain anonymous in responses to questionnaire questions to ensure privacy issues were addressed in this research.

\subsection{Data analysis}

This research utilised both descriptive and inferential statistics. The descriptive statistics involved the introduction of Nunnally (1978) mean score interpretation procedure. However, the inferential statistics involved multiple regression statistical model. Also, the statistical package for social sciences (SPSS) was utilised in coding the data gathered for this research into the computer system. The preliminary data analysis was conducted by introducing exploratory factor analysis, normality test and intercorrelation analysis. The normality test revealed abnormality in data, which is not a problem due to the introduction of respondents that exceeds thirty (30) in this research. Pallant (2013 p.214) revealed that the 'violation' of normality assumptions is solvable if a researcher introduced large respondents, which exceeded thirty (30).

In the exploratory factor analysis this research utilised principal component analysis method and varimax orthogonal rotation, which revealed that nine (9) factors were extracted. Before, the EFA there were sixty-four (64) items in this research. After, the EFA the items were reduced to thirty-five (35) items. The nine (9) factors that were extracted in this research revealed Eigenvalues that was minimum for cultural belief 
factor 1.00 and maximum for performance expectancy factor 7.96. The percentage of total variance explained by these factors was $61.35 \%$. The indicator of Kaiser-MeyerOlkin (KMO) was .87. The Bartlett's test of sphericity was significant at $\left(\mathrm{X}^{2}=\right.$ $11,181.10, \mathrm{df}=630, p=.00)$.

There were no highly correlated variables in this study, which implies the absence of multicollinearity problem in this research. Also, there was significant relationship between performance expectancy, effort expectancy, social influence, facilitating conditions, behavioural intention, use behaviour, cultural belief, social belief and political belief variables at the level of $p<.05$. In addition, the calculated correlation coefficient was in the range of social belief .00 to political belief .52 .

This study utilised Baron and Kenny (1986) mediation model for mediation analysis of data. The reason being that Baron and Kenny (1986) mediation model remains very relevant for mediation analysis in this twenty-first century. For instance, van Schaaijk et al. (2020) with Chen et al. (2020) method of mediation analysis is consistent with this research use of Baron and Kenny (1986) mediation model.

\section{Results}

\subsection{Descriptive statistics}

\subsubsection{The level of behavioural intention of using podcast among lecturers in federal universities in Nigeria}

This section's results refer to research question one. The research question one seeks to know the level of behavioural intention. The mean score for the level of behavioural intention (BHI) was $1.60(S D=.785)$. These findings revealed that behavioural intention of using podcast among lecturers in Federal Universities in Nigeria was at a low level. The findings of this research revealed that the mean scores range was from highest to lowest value of BHI5 1.61 to BHI1 1.50 among each item on lecturer's behavioural intention of using podcast in Federal Universities in Nigeria. The low mean score revealed $M=1.60$, which suggested that podcast acceptance is inadequately anticipated as part of classroom instructional media. Podcast acceptance is not part of what the lecturers intend to consider for classroom practices. See Table 1 for details.

$\mathrm{BHI}$ is synonymous to behavioural intention.

Table 1 Summary on level of behavioural intention of using podcast among lecturers in Federal universities in Nigeria.

Source: Anonymous (n.d. p.126)

\begin{tabular}{llll}
\hline & Mean & SD & Level \\
\hline \multicolumn{2}{c}{ Behavioural intention } & & \\
BHI1 & 1.50 & .770 & \\
BHI3 & 1.55 & .829 & \\
BHI4 & 1.56 & .761 & \\
BHI5 & 1.61 & .759 & Low \\
BHI6 & 1.57 & .808 & \\
Mean & 1.60 & .785 & \\
\hline
\end{tabular}


The BHI1, BHI3, BHI4, BHI5 and BHI6 are factor analysis products on behavioural intention variable. The BHI2 factor was eliminated during factor analyses due to its redundancy.

\subsection{Inferential statistics}

\subsubsection{The significant mediating influence of behavioural intention on the relationship between each independent variable and use behaviour}

This data analysis is for hypothesis one $\left(\mathrm{HO}_{1}\right)$. The $\mathrm{HO}_{1}$ tested the hypothesis to know significant mediator influence of behavioural intention on the relationship between each independent variable and use behaviour. This research identified the significant mediating influence of behavioural intention of Nigerian lecturers' towards using podcast on the relationship between performance expectancy, effort expectancy, social influence, facilitating conditions, cultural belief, social belief, political belief and use behaviour. Hierarchical multiple regression (HMR) was used to test the mediating role of behavioural intention. The findings of the hierarchical multiple regression (HMR) must be revealed in four stages (Baron and Kenny 1986). The first, second, third and fourth steps must reveal the influence of ' $\mathrm{X}-\mathrm{Y}, \mathrm{M}-\mathrm{Y}, \mathrm{X}-\mathrm{M}$ and $\mathrm{M}$ on X-Y' respectively (Baron and Kenny 1986; Kenny 2018 p.3).

The researcher performed the mediation analysis by following Baron and Kenny (1986) mediation model. Kenny (2018) referred to Baron and Kenny (1986) regarding the four rules to follow in mediation analysis. These rules are ' $\mathrm{X}-\mathrm{Y}, \mathrm{M}-\mathrm{Y}, \mathrm{X}-\mathrm{M}$ and $\mathrm{M}$ on X-Y' (Baron and Kenny 1986; Kenny 2018, p.3). The $\mathrm{X}=$ independent variable, $\mathrm{Y}=$ dependent variable and $\mathrm{M}=$ mediating variable. The first procedure was to test the significant influence of independent variables (IV) on dependent variable (DV). This first procedure regression analysis was performed on one-to-one basis. The findings revealed that all the seven independent variables are significant factors. These significant factors are performance expectancy, effort expectancy, social influence, facilitating conditions, cultural belief, social belief and political belief.

The second procedure was performed to test the significant influence of mediating variable (MV), which is behavioural intention on use behaviour as dependent variable (DV). The findings of MV to DV analysis revealed that behavioural intention had significant influence on use behaviour $(\beta=.50, p=.00)$. The use behaviour is a dependent variable (DV). Hence, this result showed that behavioural intention significantly influenced use behaviour. This result is in accordance with the 'M-Y' rule by Baron and Kenny (1986) as contained in Kenny (2018, p.3).

The third procedure was conducted to test the significant influence of each of the independent variables (IV) on mediating variable (MV). The independent variables are performance expectancy, effort expectancy, social influence, facilitating conditions, cultural belief, social belief and political belief. Also, the mediating variable is behavioural intention. The result showed that five of the seven independent variables are significant factors.

The fourth procedure was conducted to test the significant influence of mediating variable (MV) on both independent and dependent variables (IV and DV) in this research. The procedure used the hierarchical multiple regression statistics. The findings of MV on IV and DV analyses are summarised in the following Table 2: 
Table 2 The significant mediator influence of behavioural intention on the relationship between each independent variable and use behaviour of Nigerian lecturers for podcast. Source: Anonymous (n.d. p.149, $150,151,152,153,154$ and 155)

\begin{tabular}{|c|c|c|c|}
\hline Variable & $\begin{array}{l}\text { Behavioural } \\
\text { Intention (BHI) }\end{array}$ & $\begin{array}{l}\text { Dependent } \\
\text { Use Behaviour } \\
\text { (without BHI) }\end{array}$ & $\begin{array}{l}\text { Variable } \\
\text { Use Behaviour } \\
\text { (with BHI) }\end{array}$ \\
\hline
\end{tabular}

Independent Variable

Performance Expectancy

Mediator

Behaviour Intention $.50 *$

$\mathrm{R}$

.50

.31

$\mathrm{R}^{2}$

.22

.48

Adjusted $\mathrm{R}^{2}$

.22

.23

F Value

$227.94 *$

$84.83 *$

$123.66^{*}$

Independent Variable

Effort Expectancy

Mediator

Behaviour Intention

$\mathrm{R}$

$\mathrm{R}^{2}$

Adjusted $\mathrm{R}^{2}$

F Value

Independent Variable

Social Influence

Mediator

Behaviour Intention

$\mathrm{R}^{2}$

Adjusted $\mathrm{R}^{2}$

F Value

Independent Variable

Facilitating Conditions

Mediator

Behaviour Intention

$\mathrm{R}^{2}$

Adjusted $\mathrm{R}^{2}$

F Value 
Table 2 (continued)

\begin{tabular}{|c|c|c|c|}
\hline Variable & $\begin{array}{l}\text { Behavioural } \\
\text { Intention (BHI) }\end{array}$ & $\begin{array}{l}\text { Dependent } \\
\text { Use Behaviour } \\
\text { (without BHI) }\end{array}$ & $\begin{array}{l}\text { Variable } \\
\text { Use Behaviour } \\
\text { (with BHI) }\end{array}$ \\
\hline \multicolumn{4}{|l|}{ Independent Variable } \\
\hline Cultural Belief & & $.36^{*}$ & $.28 *$ \\
\hline \multicolumn{4}{|l|}{ Mediator } \\
\hline Behaviour Intention & $.50 *$ & & $.41^{*}$ \\
\hline $\mathrm{R}$ & .50 & .36 & .54 \\
\hline $\mathrm{R}^{2}$ & .22 & .13 & .29 \\
\hline Adjusted $\mathrm{R}^{2}$ & .22 & .13 & .29 \\
\hline F Value & $227.94 *$ & $125.55^{*}$ & $169.55^{*}$ \\
\hline \multicolumn{4}{|l|}{ Independent Variable } \\
\hline Social Belief & & $.11^{*}$ & $.12^{*}$ \\
\hline \multicolumn{4}{|l|}{ Mediator } \\
\hline Behaviour Intention & $.50 *$ & & $.47^{*}$ \\
\hline $\mathrm{R}$ & .50 & .11 & .48 \\
\hline $\mathrm{R}^{2}$ & .22 & .01 & .23 \\
\hline Adjusted $\mathrm{R}^{2}$ & .22 & .01 & .23 \\
\hline F Value & $227.94 *$ & $10.39 *$ & $123.11^{*}$ \\
\hline \multicolumn{4}{|l|}{ Independent Variable } \\
\hline Political Belief & & $.36^{*}$ & $.16^{*}$ \\
\hline \multicolumn{4}{|l|}{ Mediator } \\
\hline Behaviour Intention & $.50 *$ & & $.38^{*}$ \\
\hline $\mathrm{R}$ & .50 & .36 & .48 \\
\hline $\mathrm{R}^{2}$ & .23 & .13 & .23 \\
\hline Adjusted $\mathrm{R}^{2}$ & .23 & .13 & .23 \\
\hline F Value & $227.94 *$ & $120.24 *$ & $126.68 *$ \\
\hline
\end{tabular}

*= significant factor. $p<.05$ level

This Table 2 shows the result of hierarchical multiple regression analyses to investigate the mediator role of behavioural intention on the relationship between performance expectancy and use behaviour. The result was revealed in three steps. In step one the result showed that performance expectancy had a significant influence on use behaviour $(\beta=.32, p=.00)$. In step two the behavioural intention has a significant influence on use behaviour $(\beta=.50, \mathrm{p}=.00)$. In step three the performance expectancy had a significant influence on use behaviour $(\beta=.13, \mathrm{p}=.00)$. The result revealed that $\beta$ value of performance expectancy decreased in step three when compared with the $\beta$ value in step one. However, the $\beta$ value of behavioural intention decreased in step three and it was significant. Hence, the result of the hierarchical regression analysis showed 
that behavioural intention was a significant mediator of the relationship between performance expectancy and use behaviour (see Table 2 for details).

The testing of $\mathrm{HO}_{1}$ to know significant mediator influence of behavioural intention on variance changes in relationship between effort expectancy and use behaviour was revealed in three steps. In step one the result showed that effort expectancy had a significant influence on use behaviour $(\beta=.28, p=.00)$. In step two the behavioural intention had a significant influence on use behaviour $(\beta=.50, \mathrm{p}=.00)$. In step three the effort expectancy has a significant influence on use behaviour $(\beta=.10, p=.00)$. The result revealed that $\beta$ value of effort expectancy decreased in step three when compared with the $\beta$ value in step one. However, the $\beta$ value of behavioural intention decreased in step three and it was significant. Hence, the result of the hierarchical regression analysis showed that behavioural intention was a significant mediator of the relationship between effort expectancy and use behaviour (see Table 2 for details).

The testing of $\mathrm{HO}_{1}$ to know significant mediator influence of behavioural intention on variance changes in relationship between social influence and use behaviour result was revealed in three steps. In step one the result showed that social influence had a significant influence on use behaviour $(\beta=.45, p=.00)$. In step two the behavioural intention has a significant influence on use behaviour $(\beta=.50, p=.00)$. In step three the social influence has a significant influence on use behaviour $(\beta=.31, p=.00)$. The result revealed that $\beta$ value of social influence decreased in step three when compared with the $\beta$ value in step one. However, the $\beta$ value of behavioural intention decreased in step three and it was significant. Hence, the result of the hierarchical regression analysis showed that behavioural intention was a significant mediator of the relationship between social influence and use behaviour (see Table 2 for details).

The testing of $\mathrm{HO}_{1}$ to know significant mediator influence of behavioural intention on variance changes in relationship between facilitating conditions and use behaviour was revealed in three steps. In step one the result showed that facilitating conditions had a significant influence on use behaviour $(\beta=.17, p=.00)$. In step two the behavioural intention had a significant influence on use behaviour $(\beta=.50, p=.00)$. In step three the facilitating conditions had a significant influence on use behaviour $(\beta=.15$, $p=.00$ ). The result revealed that $\beta$ value of facilitating conditions decreased in step three when compared with the $\beta$ value in step one. However, the $\beta$ value of behavioural intention decreased in step three and it was significant. Hence, the result of the hierarchical regression analysis showed that behavioural intention was a significant mediator of the relationship between facilitating conditions and use behaviour (see Table 2 for details).

The testing of $\mathrm{HO}_{1}$ to know significant mediator influence of behavioural intention on variance changes in relationship between cultural belief and use behaviour was revealed in three steps. In step one the result showed that cultural belief has a significant influence on use behaviour $(\beta=.36, p=.00)$. In step two the behavioural intention has a significant influence on use behaviour $(\beta=.50, p=.00)$. In step three the cultural belief has a significant influence on use behaviour $(\beta=.28, p=.00)$. The result revealed that $\beta$ value of cultural belief decreased in step three when compared with the $\beta$ value in step one. However, the $\beta$ value of behavioural intention decreased in step three and it was significant. Hence, the result of the hierarchical regression analysis 
showed that behavioural intention was a significant mediator of the relationship between cultural belief and use behaviour (see Table 2 for details).

The testing of $\mathrm{HO}_{1}$ to know significant mediator influence of behavioural intention on variance changes in relationship between social belief and use behaviour was revealed in three steps. In step one the result showed that social belief has a significant influence on use behaviour $(\beta=.11, p=.00)$. In step two the behavioural intention has a significant influence on use behaviour $(\beta=.50$, $\mathrm{p}=.00)$. In step three the social belief has a significant influence on use behaviour ( $\beta=.12, p=.00)$. The result revealed that $\beta$ value of social belief increased in step three when compared with the $\beta$ value in step one. However, the $\beta$ value of behavioural intention decreased in step three and it was significant. Hence, the result of the hierarchical regression analysis showed that behavioural intention was a significant mediator of the relationship between social belief and use behaviour (see Table 2 for details).

This testing of $\mathrm{HO}_{1}$ to know significant mediator influence of behavioural intention on variance changes in relationship between political belief and use behaviour was revealed in three steps. In step one the result showed that political belief had a significant influence on use behaviour $(\beta=.36, p=.00)$. In step two the behavioural intention has a significant influence on use behaviour $(\beta=.50, p=.00)$. In step three the political belief factor has a significant influence on use behaviour $(\beta=.16, p=.00)$. The result in this Table 2 revealed that $\beta$ value of political belief decreased in step three when compared with the $\beta$ value in step one. However, the $\beta$ value of behavioural intention decreased in step three and it was significant. Hence, the result of the hierarchical regression analysis showed that behavioural intention was a significant mediator of the relationship between political belief and use behaviour (see Table 2 for details).

The four (4) procedures performed revealed that behavioural intention had satisfied the significant criteria for mediating test. The significant factors for mediating test are summarized in Fig. 4 that follows.

The Fig. 4 mediator test was determined by the mediating role of behavioural intention on performance expectancy, effort expectancy, social influence, facilitating conditions, cultural belief, social belief, political belief and use behaviour.

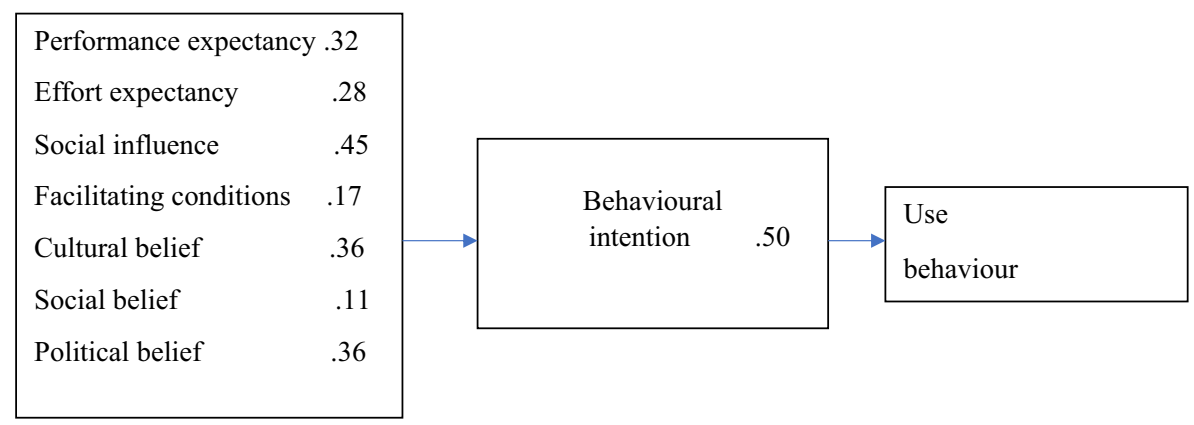

Fig. 4 Summary of variables identification for mediator test on behavioural intention. Source: Anonymous (n.d. p.157) 


\subsection{Analysis}

The findings from mediating role of behavioural intention revealed that the $\beta$ values of performance expectancy, effort expectancy, facilitating conditions, cultural belief, social belief and political belief decreased in step three (3) and significant with mediating variable compared to $\beta$ values in step one (1). Hence, the findings of the hierarchical regression analyses showed that behavioural intention was a partial mediator on the relationship between performance expectancy, effort expectancy, facilitating conditions, social belief, political belief, social influence, cultural belief and use behaviour. The findings showed that there was a significant mediating influence of behavioural intention on the relationship between each independent variable and use behaviour. Hence, hypothesis one $\left(\mathrm{HO}_{1}\right)$ was rejected.

\section{Discussion}

\subsection{The level of behavioural intention of using podcast among lecturers in Nigeria federal universities}

This section discusses research question 1. The behavioural intention level is the extent at which lecturers inner motive helps in promoting the acceptance of podcast in Nigeria Federal universities (Sarkar et al. 2020). The lecturer's behavioural intention is related to behaviour and thought of lecturers towards podcast acceptance (Kapoor and Dwivedi 2020). The word behavioural is an adjective to qualify behaviour (Hegazi et al. 2020). However, behaviour is a noun that refers to potential users' conduct towards technology acceptance (Haryono 2020). Intention is a noun word that refers to potential plan towards technology acceptance (Kusumawati et al. 2020).

The findings of the level of behavioural intention factor among lecturers' in Nigeria Federal universities revealed a low-level result. This suggested the inadequacy in behavioural intention factor among Nigeria Federal universities lecturers. Hence, these findings revealed behavioural intention as a militating issue against lecturers' acceptance of podcast in Nigeria Federal universities. This finding is consistent with Yeop et al. (2019) study, which considered behavioural intention factor as one of the factors affecting technology adoption for education. Also, Marcelo and Yot-Dominguez (2019) study asserted that the behaviour of educators towards technology adoption is at a low level, which is consistent with this research findings. Kaliisa et al. (2019) study revealed that the adoption of technologies in third world countries is still at a low level, which is consistent with this study finding that was conducted in a third world country like Nigeria.

\subsection{The significant mediator influence of behavioural intention on the relationship between each independent variable and use behaviour}

This section discusses research question 2 results based on the research objectives, which addressed each independent variable relationship with use behaviour as follows. 


\subsection{Performance expectancy and use behaviour}

The result starts with significant mediator influence of behavioural intention on variance changes in relationship between performance expectancy and use behaviour of Nigerian lecturers on podcast, which is the ability of behavioural intention factor to predict the interaction between performance expectancy and use behaviour. The behavioural intention factor is entered into the statistical package for social sciences (SPSS) in step to mediate the relationship between performance expectancy and use behaviour of Nigerian lecturers on podcast during analysis. Mediating effect is the process of testing a factor's interfering role in a study without conducting experiment (Lin et al. 2020).

The finding showed that behavioural intention significantly mediated the variance changes in relationship between performance expectancy and use behaviour of Nigerian lecturers on podcast. This finding is consistent with Rahi and Abd. Ghani (2019) finding that suggested performance expectancy as a significant mediator of the relationship between effort expectancy and intention to use technology. Binnawas et al. (2019) study considered behavioural intention as dependent variable. Kwade et al. (2019) addressed the mediating influence of danger awareness. The results derived from Binnawas et al. (2019) and Kwade et al. (2019) study are consistent with this research finding, which revealed behavioural intention as significant mediator.

\subsection{Effort expectancy and use behaviour}

The significant mediator influence of behavioural intention on variance changes in relationship between effort expectancy and use behaviour of Nigerian lecturers on podcast is the ability of behavioural intention factor to predict the interaction between effort expectancy and use behaviour of Nigerian lecturers on podcast. The researcher utilised the hierarchical multiple regression statistics to analyse the mediating role of behavioural intention factor in this research. A mediator is not a moderator since testing for mediating effect do not involve experiment (Movahedisaveji and Shaukat 2020).

The finding revealed that behavioural intention is a significant mediator of the relationship between effort expectancy and use behaviour of Nigerian lecturers on podcast. Lee et al. (2019) study considered effort expectancy as predictor of intention to use technology. Chen and Melon (2018) study likewise considered effort expectancy as predictor of intention to use technology. Hence, Lee et al. (2019) and Chen and Melon (2018) results are consistent, which suggested behavioural intention as significant mediator of the relationship between effort expectancy and use behaviour of technology.

\subsection{Social influence and use behaviour}

The significant mediator influence of behavioural intention on variance changes in relationship between social influence and use behaviour of Nigerian lecturers on podcast implies the ability of lecturers' inner motive to predict the variance changes in relationship between social influence and use behaviour. A mediator is a variable that is capable of influencing the impact of all other variables in a model (Guo et al. 2020). 
The finding revealed that behavioural intention is a significant mediator of the relationship between social influence and lecturers' use behaviour of podcast. This finding is consistent with Bassiouni et al. (2019) research findings, which revealed that behavioural intention positively impacts technology adoption. Revythi and Tselios (2019) study considered behavioural intention as dependent variable. Purani et al. (2019) likewise considered behavioural intention as dependent variable. The results from Revythi and Tselios (2019) with Purani et al. (2019) is consistent with this research question findings, which suggested behavioural intention as significant mediator.

\subsection{Facilitating conditions and use behaviour}

The significant mediator influence of behavioural intention on variance changes in relationship between facilitating conditions and use behaviour of Nigerian lecturers on podcast implies the ability of lecturers' inner motive to significantly predict the relationship between facilitating conditions and use behaviour. The hierarchical multiple regression statistics was utilised for the analysis. A mediating variable interferes in the impact of other variables in a model (Putra et al. 2020).

The finding revealed that behavioural intention is a significant mediator of the relationship between facilitating conditions and use behaviour of Nigerian lecturers on podcast. Also, Han and Yi (2019) study considered behavioural intention as independent factor. The Han and Yi (2019) result is consistent with this research findings, which revealed behavioural intention as significant mediator.

\subsection{Cultural belief and use behaviour}

The significant mediator influence of behavioural intention on variance changes in relationship between cultural belief and use behaviour of Nigerian lecturers on podcast implies the ability of behavioural intention to intervene in the interaction between cultural belief and use behaviour of podcast. This study calculated this mediating relationship by using hierarchical multiple regression. A mediating factor acts as intermediary between two or more factors in a model (Kim et al. 2020).

The finding revealed that behavioural intention is a significant mediator of the relationship between cultural belief and use behaviour of podcast. Wang et al. (2019) study revealed intention as dependent factor. However, Gkargkavouzi et al. (2019) study treated behavioural intention as independent factor. The results by Wang et al. (2019) and Gkargkavouzi et al. (2019) are consistent with this research findings, which showed that behavioural intention is a significant mediator.

\subsection{Social belief and use behaviour}

The significant mediator influence of behavioural intention on variance changes in relationship between social belief and use behaviour of Nigerian lecturers on podcast implies the ability of behavioural intention to impact the interaction between social belief and use behaviour of podcast. A mediating factor intercedes in the impact of the relationship between other factors (Khouroh et al. 2020). 
The finding revealed behavioural intention as a significant mediator of the relationship between social belief and use behaviour of podcast. Salimi (2019) study revealed intention as dependent factor. Likewise, Huang et al. (2019) study revealed intention as dependent factor. The studies by Salimi (2019) and Huang et al. (2019) are consistent with this research findings, which presented behavioural intention as significant mediator of intention.

\subsection{Political belief and use behaviour}

The significant mediator influence of behavioural intention on variance changes in relationship between political belief and use behaviour of Nigerian lecturers on podcast implies the capability of behavioural intention factor to impact the interaction between political belief factor and use behaviour. This mediating influence of behavioural intention on the relationship between political belief and use behaviour was calculated by using hierarchical multiple regression statistics in this study. A mediating factor steps into the relationship between two or more variables in a model (Abdul-Talib et al. 2020).

The finding suggested that behavioural intention was a significant mediator of the relationship between political belief and use behaviour of podcast. Mahmood et al. (2019) study revealed intention as dependent factor. Garcia et al. (2019) study likewise addressed intention as dependent factor. The studies by Mahmood et al. (2019) and Garcia et al. (2019) are consistent with this research findings, which treated behavioural intention as significant mediator.

\section{Conclusion and recommendation}

This research findings conclude that there must be drastic upgrade of Nigeria Federal universities learning technologies system to support the acceptance of podcast for teaching and learning activities. In addition, educating the instructors on the use and value of the available technologies has effect on lecturer's behavioural intention to use podcast technologies.

Also, this research contributes to existing literature in UTAUT by considering the behavioural intention factor in relation to podcast technology in Nigeria Federal universities. The reason being that there exist limited research evidences addressing the influence of behavioural intention factor on the adoption of podcasts in Nigeria Federal universities. Hence, this research contributed to existing literature in UTAUT by creating more awareness among Nigeria Federal universities lecturers on the essence of anticipated behaviour towards podcast for educational activities.

This study recommends that lecturers must change behavioural intention thought towards podcast to promote its acceptance in Nigeria Federal universities. Behavioural intention factor is related to lecturers' inner motive. The lecturers' inner motive is a kind of feeling towards podcast. Based on this research finding which suggested that behavioural intention has a partial mediating role on factors considered in this study. This research result thus implies that lecturers' behavioural intention towards podcast acceptance determines numerous element that affect podcast adoption for education in Nigeria Federal universities. The mediating role of behavioural intention factor in this 
research showed that behavioural intention takes a center stage in determining the acceptance of podcast in Nigeria Federal universities. The behavioural intention factor has a central role in predicting other factors influence in this research based on its mediating quality. Hence, lecturers must change face-to-face classroom culture of lecturing with podcast utilisation in Nigeria Federal universities. Some of the changes are achievable by adopting 'sustainability marketing' blueprint by Lim (2016, p.242), which places technology as paramount for meaningful transformation.

Acknowledgements Not applicable.

Author's contributions Adu E I: Writing original draft, Conceptual Framework, Methodology. Supervision: Azidah A Z: Instrument Validation. Aziah B I: Instrument Validation.

Funding This research did not receive any funding.

Data availability This research data is available upon request.

\section{Compliance with ethical standards}

Competing interests There is no competing interest in this research.

\section{References}

Abdul-Talib, A. N., Alanazi, T. A., Ashari, H., \& Zamani, S. N. M. (2020). Re-examining the relationship between teamwork quality and speed of new product development: A test of mediation model. In C. Bryan \& S. Fatima (Eds.), Theoretical and applied mathematics in international business (pp. 21-39). USA: IGI Global.

Abioye, T. (2011). A socio-cultural analysis of Yoruba discourse patterns in selected child welfare clinics in southwestern Nigeria. Cross-Cultural Communication, 7(4), 71-82.

Adu, E. I. (2017). Influence of teachers orientation on podcast utilisation in schools. Journal of Education and Practice, 8(2), 56-61.

Ahlan, A., Atanda, B. N., \& Isah, Y. (2014). Information technology enhances students' academic performance: A case of University of Ilorin. The Online Journal of Distance Education and e-Learning, 2(2), $15-20$.

Ahmadi, H. (2019). Principles of authenticity in second language instructional materials development: A social-constructivist perspective. Journal of Applied Linguistics and Language Research, 6(3), 132-138.

Ajzen, I. (1991). The theory of planned behavior. Organizational Behavior and Human Decision Processes, 50(2), 179-211.

Ajzen, I., \& Fishbein, M. (1969). The prediction of behavioral intentions in a choice situation. Journal of Experimental Social Psychology, 5(1), 400-416.

Alryalat, M. A. A., Rana, N. P., \& Dwivedi, Y. K. (2020). Citizen's adoption of an E-government system: Validating the extended theory of reasoned action (TRA). In Information Resources Management Association (Ed.), Open government: Concepts, methodologies, tools, and applications (pp. 651-674). USA: IGI Global.

Al-Saedi, K., Al-Emran, M., Abusham, E., \& El Rahman, S. A. (2019, February). Mobile payment adoption: A systematic review of the UTAUT model. In 2019 International Conference on Fourth Industrial Revolution (ICFIR) (pp. 1-5). IEEE. Gulf International Exhibition Center, Gulf Hotel, Kingdom of Bahrain.

Ang'ondi, E. K. (2013, July). Teachers attitudes and perceptions on the use of ICT in teaching and learning as observed by ICT champions. In Proc. 10th IFIP World Conference on Computers in Education. Toruń, Poland. 
Anonymous. (n.d.). Lecturers acceptance of Podcast in South-West Nigeria Federal Universities. Unpublished $\mathrm{PhD}$ Thesis.

Ayoade, O. B. (2015). Factors influencing students' behavioural intention to adopt and use mobile learning in higher educational institutions in Nigeria: An example of Ekiti State University, Ado-Ekiti. International Journal of Emerging Technology and Advanced Engineering, 5(4), 307-313.

Ayodele, J. B., \& Akindutire, I. O. (2009). The production of quality teachers to boost the efficiency of Nigeria's education system. Research in Education, 81(1), 43-52.

Babatope, B. A. (2010). Problems of facilities in south west Nigerian universities and the way forward. International Journal of Educational Administration and Policy Studies, 2(2), 039-043.

Barakabitze, A. A., William-Andey Lazaro, A, Ainea, N, Mkwizu, M. H., Maziku, H, Matofali, A. X, Iddi, A, \& Sanga, C. (2019). Transforming African education systems in Science, Technology, Engineering, and Mathematics (STEM) using ICTs: Challenges and opportunities. Retrieved from http://downloads. hindawi.com/journals/edri/2019/6946809.pdf

Barnes, J., \& Kennewell, S. (2017). Investigating teacher perceptions of teaching ICT in Wales. Education and Information Technologies, 22(5), 2485-2497.

Baron, R. M., \& Kenny, D. A. (1986). The moderator-mediator variable distinction in social psychological research: Conceptual, strategic, and statistical considerations. Journal of Personality and Social Psychology, 51(6), 1173-1182.

Bassiouni, D. H., Hackley, C., \& Meshreki, H. (2019). The integration of video games in family-life dynamics: An adapted technology acceptance model of family intention to consume video games. Information Technology \& People, 32(6), 1376-1396.

Berry, R. (2015). A golden age of podcasting? Evaluating serial in the context of podcast histories. Journal of Radio \& Audio Media, 22(2), 170-178.

Binnawas, M. S. H., Khalifa, G. S., \& Bhaumick, A. (2019). The influence of higher education service quality on Behavioural intention: The mediating role of student happiness. Restaurant Business, 118(10), 444 458.

Borisade, T. F. (2013). Falling standard of education: A case of Ekiti state College of Education. European Scientific Journal, 9(19), 112-122.

Bralić, A., \& Divjak, B. (2018). Integrating MOOCs in traditionally taught courses: Achieving learning outcomes with blended learning. International Journal of Educational Technology in Higher Education, $15(1), 2$.

Brodahl, C., Hadjerrouit, S., \& Hansen, N. K. (2011). Collaborative writing with web 2.0 technologies: Education students' perceptions. Journal of Information Technology Education, 10(1), 73-103.

Chen, Z., \& Melon, J. (2018). Evolution of social media: Review of the role of podcasts in gynecology. International Urogynaecology Journal, 29(4), 477-480.

Chen, M., Huang, C., Feng, W., Li, Y., \& Wu, Y. (2020). C-reactive protein mediates the association between leisure-time physical activity and lung function in middle-aged and older adults. BMC Public Health, $20(1), 6$.

Clark, E., Mulgrew, K., Kannis-Dymand, L., Schaffer, V., \& Hoberg, R. (2019). Theory of planned behaviour: Predicting tourists' pro-environmental intentions after a humpback whale encounter. Journal of Sustainable Tourism, 27(5), 649-667.

Clarke, C. G., Nnajiuba, U., Howie, J., Khan, M., dos Santos, D. P., \& Ranschaert, E. (2020). Giving radiologists a voice: A review of podcasts in radiology. Insights into Imaging, 11(1), 1-9.

David, O. N., Iahad, A. N., \& Rahim, N. Z. A. (2012). The impact of UTAUT model and ICT theoretical framework on university academic staff: Focus on Adamawa State University, Nigeria. International Journal of Computers \& Technology, 2(2), 102-111.

De Vivo, M., \& Mills, H. (2019). Physical activity profiling during pregnancy: Application of the Theory of Planned Behaviour by scrutinising the role of past behaviour. Retrieved from https://osf.io/x4tbw/ download

Ding, A. C. E., Ottenbreit-Leftwich, A., Lu, Y. H., \& Glazewski, K. (2019). EFL teachers' pedagogical beliefs and practices with regard to using technology. Journal of Digital Learning in Teacher Education, 35(1), 20-39.

Echezona, R. I., \& Ugwuanyi, C. F. (2010). African university libraries and internet connectivity: Challenges and the way forward. Library Philosophy and Practice, 3(9), 1-13.

Eze, A. B. (2013). The readiness of universities in managing electronic records: A study of three federal universities in Nigeria. The Electronic Library, 31(6), 792-807.

Eze, S. C., Chinedu-Eze, V. C., \& Bello, A. O. (2018). The utilisation of e-learning facilities in the educational delivery system of Nigeria: A study of M-University. International Journal of Educational Technology in Higher Education, 15(1), 3443. 
FME. (2011). Nigeria digest of education statistics 2006-2010. Nigeria: Editors.

Foluke, O. (2019). Determinants of electronic book adoption in Nigeria. DESIDOC Journal of Library \& Information Technology, 39(4), 175-183.

Garcia, J., Arroyo, R., Mars, L., \& Ruiz, T. (2019). The influence of attitudes towards cycling and walking on travel intentions and actual behavior. Sustainability, 11(9), 1-10.

Garone, A., Pynoo, B., Tondeur, J., Cocquyt, C., Vanslambrouck, S., Bruggeman, B., \& Struyven, K. (2019). Clustering university teaching staff through UTAUT: Implications for the acceptance of a new learning management system. British Journal of Educational Technology, 50(5), 2466-2483.

Garuba, A. R. (2013). The prospects of bridging the digital divide in Africa. Library Philosophy \& Practice, 2(1), 13-14.

Gkargkavouzi, A., Halkos, G., \& Matsiori, S. (2019). Environmental behavior in a private-sphere context: Integrating theories of planned behavior and value belief norm, self-identity and habit. Resources, Conservation and Recycling, 148(1), 145-156.

Glasow, P. A. (2005). Fundamentals of survey research methodology. Retrieved from http://www.uky.edu/ $\sim$ kdbrad2/EPE619/Handouts/SurveyResearchReading.pdf

Guo, Y., Wang, L., \& Chen, Y. (2020). Green entrepreneurial orientation and green innovation: The mediating effect of supply chain learning. UK: SAGE Open.

Hagger, M. S. (2019). The reasoned action approach and the theories of reasoned action and planned behavior. In D. S. Dunn (Ed.), Oxford bibliographies in psychology. NY: Oxford University Press. https://doi.org/ 10.1093/OBO/9780199828340-0240.

Hall, A., Turner, L., \& Kilpatrick, S. (2019). Using the theory of planned behaviour framework to understand Tasmanian dairy farmer engagement with extension activities to inform future delivery. The Journal of Agricultural Education and Extension, 25(3), 195-210.

Han, S., \& Yi, Y. J. (2019). How does the smartphone usage of college students affect academic performance? Journal of Computer Assisted Learning, 35(1), 13-22.

Haryono, A. (2020). Sensitive language behaviour as a trigger of the conflict within interethnic family in Tapal Kuda Region. Retrieved from http://ura.unej.ac.id/bitstream/handle/123456789/71083/T.4.pdf? sequence $=1$

Hegazi, M., Neumann, K., \& Rosenfeld, J. (2020). Prevention of developmental disorders of speech and language. In A. Zehnhoff-Dinnesen, B. Wiskirska-Woznica, K. Neumann, \& T. Nawka (Eds.), Phoniatrics I (pp. 713-724). Berlin, Heidelberg: Springer.

Hersch, C.R. (2017). How to create your own podcast series. Retrieved from https://www.apa.org/monitor/ 2017/12/create-podcast

Hew, K. F. (2009). Use of audio podcast in K-12 and higher education: A review of research topics and methodologies. Educational Technology Research and Development, 57(3), 333-357.

Huang, J. W., \& Li, Y. H. (2017). Green innovation and performance: The view of organizational capability and social reciprocity. Journal of Business Ethics, 145(2), 309-324.

Huang, F., Teo, T., \& Zhou, M. (2019). Chinese students' intentions to use the internet-based technology for learning. Educational Technology Research and Development, 1(1), 1-17.

Ibrahim, T. A. (2018). The role of technology acceptance model in explaining university academics' acceptance and behavioural intention to use technology in education. KnE Social Sciences, 3(6), 11621172.

Idoga, P. E., Toycan, M., Nadiri, H., \& Çelebi, E. (2019). Assessing factors militating against the acceptance and successful implementation of a cloud based health center from the healthcare professionals' perspective: A survey of hospitals in Benue state, northcentral Nigeria. BMC Medical Informatics and Decision Making, 19(1), 3442.

Ifijeh, G., \& Yusuf, F. (2020). Covid-19 pandemic and the future of Nigeria's university system: The quest for libraries' relevance. The Journal of Academic Librarianship, 46(6), 102226.

Ikegbusi, N. G., Chigbo-Okeke, U. C., \& Modebelu, M. N. (2016). Politics and educational leadership in Nigerian schools: Issues and challenges. Open Access Library Journal, 3(07), 1-15.

Jacob, O. N., Abigeal, I., \& Lydia, A. E. (2020). Impact of COVID-19 on the higher institutions development in Nigeria. Electronic Research Journal of Social Sciences and Humanities, 2(2), 126-135.

Jost, J. T., Federico, C. M., \& Napier, J. L. (2009). Political ideology: Its structure, functions, and elective affinities. Annual Review of Psychology, 60(1), 307-337.

Judge, M., Warren-Myers, G., \& Paladino, A. (2019). Using the theory of planned behaviour to predict intentions to purchase sustainable housing. Journal of Cleaner Production, 215(1), 259-267.

Kabir, M. A., Saidin, S. Z., \& Ahmi, A. (2017). An examination of factors that influence employees' behavioral intention to use electronic revenue collection system in public hospitals. Journal of Telecommunication, Electronic and Computer Engineering (JTEC), 9(2-11), 109-114. 
Kaliisa, R., Palmer, E., \& Miller, J. (2019). Mobile learning in higher education: A comparative analysis of developed and developing country contexts. British Journal of Educational Technology, 50(2), 546-561.

Kaplan, A. M., \& Haenlein, M. (2010). Users of the world, unite! The challenges and opportunities of social media. Business Horizons, 53(1), 59-68.

Kapoor, K. K., \& Dwivedi, Y. K. (2020). Sustainable consumption from the consumer's perspective: Antecedents of solar innovation adoption. Resources, Conservation and Recycling, 152(1), 1-12.

Kenny D.A. (2018). Mediation. Retrieved from davidakenny.net.

Khadimally, S. (Ed.). (2019). Role of the social constructivist theory, andragogy, and computer-mediated instruction (CMI) in adult ESL learning and teaching environments: How students transform into selfdirected learners through mobile technologies. In Technology-assisted ESL acquisition and development for non-traditional learners (pp. 1-37). USA: IGI Global.

Khouroh, U., Sudiro, A., Rahayu, M., \& Indrawati, N. (2020). The mediating effect of entrepreneurial marketing in the relationship between environmental turbulence and dynamic capability with sustainable competitive advantage: An empirical study in Indonesian MSMEs. Management Science Letters, 10(3), 709-720.

Kim, Y., \& Byun, S. (2019). Effects of cyber defamation Victims' post-traumatic stress on coping behaviour: Focusing on the theory of reasoned action. Journal of the Korea Society of Digital Industry and Information Management, 15(1), 29-41.

Kim, H., Kim, S., Kong, S., \& Kim, N. H. (2020). Social provision partially mediates the complex associations among posttraumatic stress, obsessive-compulsive and depressive symptoms in traumatized patients. Journal of Advanced Nursing, 76(2), 566-576.

Kincsei, A. (2007). Technology and society in the information age. Retrieved from https://s3.amazonaws.com/ academia.edu.documents/35186597/03_Kincsei_final.pdf?

Kizgin, H., Jamal, A., Rana, N., Dwivedi, Y., \& Weerakkody, V. (2019). The impact of social networking sites on socialization and political engagement: Role of acculturation. Technological Forecasting and Social Change, 145(1), 503-512.

Krejcie, \& Morgan. (1970). Sampling method. Retrieved from http://in-troh-spective.blogspot.com on 21/12/ 2018.

Kusumawati, A., Utomo, H. S., Suharyono, S., \& Sunarti, S. (2020). Effects of sustainability on WoM intention and revisit intention, with environmental awareness as a moderator. Management of Environmental Quality: An International Journal, 31(1), 273-288.

Kwade, P. C., Lugu, B. K., Lukman, S., Quist, C. E., \& Chu, J. (2019). Farmers' attitude towards the use of genetically modified crop technology in southern Ghana: The mediating role of risk perception. AIMS Agriculture and Food, 4(4), 833-841.

Landefeld, S. (2019). The evolution of norms and concepts in international law: A social constructivist approach. In R. Deplano (Ed.), Pluralising international legal scholarship. Edward Elgar Publishing: US.

Lee, S. W., Sung, H. J., \& Jeon, H. M. (2019). Determinants of continuous intention on food delivery apps: Extending UTAUT2 with information quality. Sustainability, 11(11), 1-15.

Lemon, N., \& Garvis, S. (2019). Self-belief and confidence to teach arts and digital technology in K-6 classrooms: Perspectives from pre-service teachers. In Information Resources Management Association (Ed.), Pre-service and in-service teacher education: Concepts, methodologies, tools, and applications (pp. 234-253). USA: IGI Global.

Lim, W. M. (2016). A blueprint for sustainability marketing: Defining its conceptual boundaries for progress. Marketing Theory, 16(2), 232-249.

Lin, C. Y., Huang, C. K., \& Ko, C. J. (2020). The impact of perceived enjoyment on team effectiveness and individual learning in a blended learning business course: The mediating effect of knowledge sharing. Australasian Journal of Educational Technology, 36(1), 126-141.

Ma, L., \& Lee, C. S. (2019). Investigating the adoption of MOOC s: A technology-user-environment perspective. Journal of Computer Assisted Learning, 35(1), 89-98.

Mahmood, T. M. A. T., Al Mamun, A., Ahmad, G. B., \& Ibrahim, M. D. (2019). Predicting entrepreneurial intentions and pre-start-up behaviour among Asnaf millennials. Sustainability, 11(18), (article no: 4939).

Marcelo, C., \& Yot-Dominguez, C. (2019). From chalk to keyboard in higher education classrooms: Changes and coherence when integrating technological knowledge into pedagogical content knowledge. Journal of Further and Higher Education, 43(7), 975-988.

Mehta, A., Morris, N. P., Swinnerton, B., \& Homer, M. (2019). The influence of values on E-learning adoption. Computers \& Education, 141(1), 1-15.

Mensah, I. K. (2019). Factors influencing the intention of university students to adopt and use e-government services: An empirical evidence in China. SAGE Open, 9(2), 1-19. 
Moja, T. (2000). Nigeria education sector analysis: An analytical synthesis of performance and main issues. World Bank Report, 3, 46-56.

Movahedisaveji, M. M., \& Shaukat, B. (2020). Mediating role of brand app trust in the relationship between antecedents and purchase intentions-Iranian B2C mobile apps. Journal of Management Analytics, 7(1), 69-104.

Nisson, C., \& Earl, A. (2015). The theories of reasoned action and planned behavior: Examining the reasoned action approach to prediction and change of health behaviors. Retrieved from http:/hailab.psych.lsa. umich.edu/wp-content/uploads/2016/06/Nisson-Earl-2015_TRA-TRP-1.pdf

Nistor, N., Lerche, T., Weinberger, A., Ceobanu, C., \& Heymann, O. (2014). Towards the integration of culture into the unified theory of acceptance and use of technology. British Journal of Educational Technology, 45(1), 36-55.

Norman, P., Webb, T. L., \& Millings, A. (2019). Using the theory of planned behaviour and implementation intentions to reduce binge drinking in new university students. Psychology \& Health, 34(4), 478-496.

Ntui, A. I., \& Usang, E. I. (2014). Information and communication technology (ICT) usage and undergraduate students study habits in universities in Cross River state, Nigeria. Gale A Cengage Company: University of Nebraska-Lincoln.

Nunnally, J. C. (1978). Psychometric theory (2nd ed.). New York: McGraw-Hill.

Obilade, T. (2013). Instructional technology and distance education in Nigeria: Historical background and a critical appraisal. Distance Learning, 10(1), 25.

Okebukola, P. (2011, April). Nigerian universities and world ranking: Issues, strategies and forward planning. In Lecture presented at the conference of Association of Vice-Chancellors of Nigerian Universities, Covenant University (pp. 27-30).

Okundaye, K., Fan, S. K., \& Dwyer, R. J. (2019). Impact of information and communication technology in Nigerian small-to medium-sized enterprises. Journal of Economics, Finance and Administrative Science, 24(47), 29-46.

Oladejo, M. A., Adetoro, J. A., Oyebade, S. A., \& Adedoyin, A. O. F. (2018). Learning on the move: The behavioural intentions of nigerian students with disabilities. Malaysian Online Journal of Educational Sciences, 6(1), 1-10.

Omede, A. A. (2015). The challenges of educating the visually impaired and quality assurance in tertiary institutions of learning in Nigeria. International Journal of Educational Administration and Policy Studies, 7(7), 129-133.

Omodara, O. D., \& Adu, E. I. (2014). Relevance of educational media and multimedia technology for effective service delivery in teaching and learning processes. IOSR Journal of Research \& Methods in Education (IOSR-JRME), 4, 48-51.

Osuji, C. N. (2011). Perceived impact of politics on the management of secondary schools in South-East Nigeria (Phd Thesis). University of Nigeria, Nsukka.

Oyserman, D. (2017). Culture three ways: Culture and subcultures within countries. Annual Review of Psychology, 68, 435-463.

Pallant, J. (2013). SPSS survival manual: A step by step guide to data analysis (5th ed.). NY: Allen \& Unwin.

Panday, P. P. (2009). Simplifying podcasting. International Journal of Teaching and Learning in Higher Education, 20(2), 251-261.

Passafaro, P., Livi, S., \& Kosic, A. (2019). Local norms and the theory of planned behaviour: Understanding the effects of spatial proximity on recycling intentions and self-reported ecological behaviour. Frontiers in Psychology, 10, 744-750.

Purani, K., Kumar, D. S., \& Sahadev, S. (2019). E-loyalty among millennials: Personal characteristics and social influences. Journal of Retailing and Consumer Services, 48, 215-223.

Putra, M. D. P., Widanaputra, A. A. G. P., Ramantha, I. W., \& Gayatri, G. (2020). The effect of organizational commitments in auditor performance with dysfunctional audit behavior as mediation variables. International Research Journal of Management, IT and Social Sciences, 7(1), 45-52.

Rahi, S., \& Abd. Ghani, M. (2019). Investigating the role of UTAUT and e-service quality in internet banking adoption setting. The TQM Journal, 31(3), 491-506.

Rahi, S., Mansour, M. M. O., Alghizzawi, M., \& Alnaser, F. M. (2019). Integration of UTAUT model in internet banking adoption context. Journal of Research in Interactive Marketing, 13(3), 411-435.

Regan, P. M., \& Talat Khwaja, E. (2019). Mapping the political economy of education technology: A networks perspective. Policy Futures in Education, 17(8), 1000-1023.

Revythi, A., \& Tselios, N. (2019). Extension of technology acceptance model by using system usability scale to assess behavioral intention to use e-learning. Education and Information Technologies, 24(4), 23412355 . 
Salimi, A. R. (2019). Effects of environmental concerns and green knowledge on green product consumptions with an emphasis on mediating role of perceived behavioral control, perceived value, attitude, and subjective norm. International Transaction Journal of Engineering, Management, \& Applied Sciences \& Technologies, 10(5), 651-661.

Sarkar, S., Chauhan, S., \& Khare, A. (2020). A meta-analysis of antecedents and consequences of trust in mobile commerce. International Journal of Information Management, 50, 286-301.

Schonwetter, D. J. (1993). Attributes of effective lecturing in the college classroom. Canadian Journal of Higher Education, 23(2), 1-18.

Shiferaw, K. B., \& Mehari, E. A. (2019). Modeling predictors of acceptance and use of electronic medical record system in a resource limited setting: Using modified UTAUT model. Informatics in Medicine Unlocked, 17, 100182.

Sunny, S., Patrick, L., \& Rob, L. (2019). Impact of cultural values on technology acceptance and technology readiness. International Journal of Hospitality Management, 77, 89-96.

Tandon, U. (2020). Factors influencing adoption of online teaching by school teachers: A study during COVID-19 pandemic. Journal of Public Affairs, e2503.

Teague, R. (2000). Social constructivism \& social studies. Retrieved from https://moodle.org/pluginfile.php/ 401/mod_forum/attachment/112845/SocialCo.pdf

Tornikoski, E., \& Maalaoui, A. (2019). Critical reflections-the theory of planned behaviour: An interview with Icek Ajzen with implications for entrepreneurship research. International Small Business Journal, 37(5), 1-17.

Torres, J. M. T. (2011). The use of podcasts in higher education: Communication, innovation, education and knowledge management. International Journal of Educational Technology in Higher Education, 8(2), 225-240.

Ukwueze, F.N. \& Okpulo L.O. (2014). The use of educational podcasting in Nigerian Universities: A case study (PhD dissertation). University of Nigeria, Nsukka.

UniRank, (2018). Federal University Oye-Ekiti Ranking \& Review. Retrieved from, https://www.4icu.org/ reviews/13958.htm on 21/12/18.

van Schaaijk, A., Noor Baloch, A., Thomée, S., Frings-Dresen, M., Hagberg, M., \& Nieuwenhuijsen, K. (2020). Mediating factors for the relationship between stress and work ability over time in young adults. International Journal of Environmental Research and Public Health, 17(7), 2530.

Vega, A., Ramirez-Benavidez, K., \& Guerrero, L. A. (2019, July). Tool UTAUT applied to measure interaction experience with NAO robot. In International Conference on Human-Computer Interaction (pp. 501-512). Springer, Cham.

Venkatesh, V., Morris, M. G., Davis, G. B., \& Davis, F. D. (2003). User acceptance of information technology: Toward a unified view. MIS Quarterly, 27(3), 425-478.

Wang, M. Y., Zhang, P. Z., Zhou, C. Y., \& Lai, N. Y. (2019). Effect of emotion, expectation, and privacy on purchase intention in WeChat health product consumption: The mediating role of trust. International Journal of Environmental Research and Public Health, 16(20), (article no: 3861).

Wong, K. T., Teo, T., \& Russo, S. (2013). Interactive whiteboard acceptance: Applicability of the UTAUT model to student teachers. The Asia-Pacific Education Researcher, 22(1), 1-10.

Xiao, M. (2020). Factors influencing eSports viewership: An approach based on the theory of reasoned action. Communication \& Sport, 8(1), 92-122.

Yakubu, M. N., \& Dasuki, S. I. (2019). Factors affecting the adoption of e-learning technologies among higher education students in Nigeria: A structural equation modelling approach. Information Development, 35(3), 492-502.

Yeop, M. A., Yaakob, M. F. M., Wong, K. T., Don, Y., \& Zain, F. M. (2019). Implementation of ICT policy (blended learning approach): Investigating factors of Behavioural intention and use behaviour. International Journal of Instruction, 12(1), 767-782.

Yu, M. O. (2017). Vygotsky's social constructivism. Bulletin.

Zuidervaart, L. (2019). Social domains of knowledge: Technology, art, and religion. Philosophia Reformata, 84(1), 79-101.

Publisher's note Springer Nature remains neutral with regard to jurisdictional claims in published maps and institutional affiliations. 